\title{
BIBECHANA
}

A Multidisciplinary Journal of Science, Technology and Mathematics ISSN 2091-0762 (Print), 2382-5340 (Online)

Journal homepage: http://nepjol.info/index.php/BIBECHANA

Publisher: Research Council of Science and Technology, Biratnagar, Nepal

\section{Primary Productivity of Phytoplankton of Mahakali River, Nepal}

\section{Vinod Kumar Mahaseth}

Department of Zoology, MMAM Campus, Tribhuvan University, Biratnagar, Nepal

E-mail: vkmahaseth1962@gmail.com

Article history: Received 11 August, 2016; Accepted 4 November, 2016

DOI: http://dx.doi.org/10.3126/bibechana.v14i0.15988

This work is licensed under the Creative Commons CC BY-NC License.

https://creativecommons.org/licenses/by-nc/4.0/

\section{(c) (i) (8)}

\section{Abstract}

Present paper describes primary productivity of Mahakali river at four stations. The two years mean of net primary production was $96.80 \mathrm{mgC} / \mathrm{m}^{3} /$ day. The net primary production value of Mahakali river was less due to the low water temperature and less phytoplanktonic growth. Two years mean value of gross primary production of Mahakali river was $176.29 \mathrm{mgC} / \mathrm{m}^{3} / \mathrm{day}$, which is less than lentic water. It shows that the river is oligotrophic but developing a tendency as going towards mesotrophic.

Keywords: Mahakali River; Productivity; Phytoplankton.

\section{Introduction}

Phytoplankton, the minute chlorophyll bearing organisms, constitutes the most important component of the plankton and account for almost all the primary production in the water body. Plankton forms the base of food chain in most of the aquatic ecosystem, thus playing a vital role in fisheries. The productivity of a water body is characterized by the presence of living organisms in the natural environment. Among the biotic components of an aquatic ecosystem, plankton community plays a significant role in the productivity and the trophic balance of the system. Plankton constitutes the major source of energy in the food web of aquatic systems. Their population fluctuates, depending on the hydrological regime and saprobiotic condition of the water. Because of their short life cycles, plankton responds quickly to environmental changes. Water temperature, light intensity, velocity and discharge of water, turbidity and alkalinity have widely been reported to affect plankton density in flowing waters $[1,2]$. Some extensive investigation on various aspects of productivity has been made by Dash et al. [3], Jabde and Rokade [4] and Sharma [5]. Planktonic fauna was abundant during the post-monsoon period, when the water temperature was moderate to low, current strength was feeble and the water was calm without turbidity. Plankton, particularly phytoplankton, has been used as indicators of water quality. Phytoplankton 
productivity and biomass of river are dependent on several interrelated physical, chemical and biological factors. During the study period the Mahakali River was rapidly surveyed to evaluate their productivity in the context of plankton population.

\section{Study Area}

Mahakali River originates from Indo-Nepalese glaciers, Milan glacier of India and Lipu-lekh of Nepal. The river leaves the mountains near Tanakpur and is now known as Sarada in India. Later, it reaches Sharada barrage, where it is considerably wider. Mahakali then enters into Nepal at Chandani and flows through Nepal upto Dodhara, after which it enters into Indian Territory, finally confluencing with the Ghaghara.

The present studies were conducted at the Chandani and Dodhara V.D.C. (Village Development Committee). They are the V.D.C. of Kanchanpur district near the bank of Mahakali river. The study area lies between longitude $80^{\circ} 25^{\prime}$ East and latitude $28^{0} 35^{\prime}$ North.

Four stations (A, B, C and D) were selected. First station ' $A$ ' is an upper station, which is near at Purnagiri temple of Syavle Bajar. Second station 'B' is 4 kilometres from station A. Third station 'C', which is 4 kilometres from station B. Fourth station ' $\mathrm{D}$ ' is a lower station, which is 4 kilometres from station $\mathrm{C}$.

\section{Materials and Methods}

The present study was carried out for a period of two years from September 2003 to August 2005. This period was used to collect the quantitative data on various aspects of river ecology.

In the present investigations, samples were collected from the study area, every month at 15 days interval. Phytoplankton primary productivity was measured by "Light and Dark bottle" method [6]. Duplicate light bottles and a single dark bottle were used to determine productivity. Water from surface level was collected and filled in duplicate light and dark bottles. Another water sample (in light bottle) was also collected simultaneously for determination of initial oxygen concentration. Bottles were kept suspended into the water. After 4 - 5 hours, oxygen was determined with the help of changes in oxygen concentration in light and dark bottles, gross and net primary productivity and community respiration were determined. Oxygen values were converted to carbon values $\left(\mathrm{mg} \mathrm{C} / \mathrm{m}^{3} / \mathrm{d}\right)$ by multiplying the values with 0.375 [7].

The productivity values were calculated using following equations:

Gross primary productivity $\left(\mathrm{mg} \mathrm{C} / \mathrm{m}^{3} / \mathrm{d}\right)$

$$
P_{g}=\frac{L O-D O \times 0.375}{T \times P Q} \times 1000
$$

Net primary productivity $\left(\mathrm{mg} \mathrm{C} / \mathrm{m}^{3} / \mathrm{d}\right)$

$$
P_{n}=\frac{L O-I O \times 0.375}{T \times P Q} \times 1000
$$




$$
R=\frac{I O-D O \times 0.375}{T \times P Q} \times 1000
$$

where, $\mathrm{IO}=$ initial oxygen concentration, $\mathrm{LO}$ and $\mathrm{DO}=$ concentrations of oxygen in light and dark bottle, respectively after incubation; $\mathrm{T}=$ time, $\mathrm{PQ}$ and $\mathrm{RQ}=$ photosynthetic and respiratory quotients, respectively, which were assumed to be 1.2 [8].

\section{Results and Discussion}

The values of primary productivity of phytoplankton were observed during the whole study period (September 2003 - August 2005). It was noticed that the net primary productivity values varied from month to month (Table 1). The net primary productivity of Mahakali river was $96.80 \mathrm{mgC} / \mathrm{m}^{3} /$ day on the basis of two years mean. The maximum value was recorded in April while lowest value was recorded in July in both years. Seasonally, the minimum and maximum values ranged from $10.93-164.00 \mathrm{mgC} / \mathrm{m}^{3}$ /day during the first year and from $15.62-209.37 \mathrm{mgC} / \mathrm{m}^{3} /$ day during second year.

The community respiration values also varied from month to month. The value of community respiration was observed to be $79.49 \mathrm{mgC} / \mathrm{m}^{3} /$ day on the basis of two years mean. Community respiration values fluctuated from $18.75-321.87 \mathrm{mgC} / \mathrm{m}^{3} /$ day during first year while from $29.62-128.12 \mathrm{mgC} / \mathrm{m}^{3} /$ day during second year of investigation. The highest values were recorded in the month of February 2004 and April 2005 during the first and second years of investigation, respectively.

The values of gross primary productivity also varied from month to month as like net primary productivity and community respiration. The two years mean value of gross primary productivity was observed $176.29 \mathrm{mgC} / \mathrm{m}^{3} /$ day. The minimum and maximum values recorded from $78.11-356.24$ $\mathrm{mgC} / \mathrm{m}^{3} /$ day during first year while from $45.24-337.49 \mathrm{mgC} / \mathrm{m}^{3} /$ day during second year of study. The highest value was noticed in the month of February 2004 and April 2005 while lowest values were observed in the month of September 2003 and July 2005 during the first and second year of study.

Among the biotic components of an aquatic ecosystem, plankton community plays an important role in the productivity of any water body. The water temperature is one of the most important factor which influences the production of phytoplankton in a river system. Das and Srivastava [9] pointed out the role of temperature as limiting factor for phytoplanktonic production. Khanna et al. [2] and Joshi et al. [10]are of the same view that the planktonic production was mainly influenced by temperature. During the present investigation, maximum phytoplankton was observed during summers.

During the present investigation, the two years mean of net primary production was $96.80 \mathrm{mgC} / \mathrm{m}^{3} /$ day which was less than value of net primary production of lentic water. The net primary production value of lotic water (Mahakali river) is less due to the low water temperature and less phytoplanktonic growth. Baduni [11] and Pathani [12] also recorded low rates of productivity in Alaknanda river in Garhwal Himalayas and Sarju river in Kumaun Himalayas, respectively. 
Two years mean value of gross primary production of Mahakali river was $176.29 \mathrm{mgC} / \mathrm{m}^{3} / \mathrm{day}$, which is less than lentic water. This result is confirmed by other workers like Baduni (11) and Pathani (12). The monthly values of gross primary production varied from $78.11 \mathrm{mgC} / \mathrm{m}^{3} /$ day to $356.24 \mathrm{mgC} / \mathrm{m}^{3} /$ day and $45.24 \mathrm{mgC} / \mathrm{m}^{3} /$ day to $337.49 \mathrm{mgC} / \mathrm{m}^{3} /$ day during first and second year of investigations.

Table 1: Primary productivity of phytoplankton of Mahakali River.

\begin{tabular}{|c|c|c|c|}
\hline Month & $\begin{array}{l}\text { Net Primary } \\
\text { Production } \\
\text { mgC/m³/day }\end{array}$ & $\begin{array}{l}\text { Community } \\
\text { Respiration } \\
\text { mgC/m²/day }\end{array}$ & $\begin{array}{l}\text { Gross Primary } \\
\text { Production } \\
\mathrm{mgC}^{3} \mathrm{~m}^{3} / \text { day }\end{array}$ \\
\hline Sep. 2003 & 42.18 & 35.93 & 78.11 \\
\hline Oct. & 75.00 & 18.75 & 93.75 \\
\hline Nov. & 75.00 & 59.37 & 134.37 \\
\hline Dec. & 89.06 & 67.18 & 156.24 \\
\hline Jan.2004 & 98.43 & 82.81 & 181.24 \\
\hline Feb. & 34.37 & 321.87 & 356.24 \\
\hline Mar. & 121.87 & 220.31 & 342.18 \\
\hline Apr. & 164.00 & 179.68 & 343.68 \\
\hline May & 101.56 & 114.06 & 215.62 \\
\hline Jun. & 89.06 & 18.75 & 107.81 \\
\hline Jul. & 10.93 & 93.75 & 104.68 \\
\hline Aug. & 35.93 & 57.98 & 93.91 \\
\hline & $\begin{array}{ll}\text { Mean } & 78.11 \\
\text { S.D. } & 42.65\end{array}$ & $\begin{array}{c}105.87 \\
91.43\end{array}$ & $\begin{array}{l}183.98 \\
106.17\end{array}$ \\
\hline
\end{tabular}

$(2004 / 05)$

\begin{tabular}{|c|c|c|c|}
\hline Sep. 2004 & 62.50 & 29.68 & 92.18 \\
\hline Oct. & 81.25 & 31.25 & 112.5 \\
\hline Nov. & 121.87 & 42.18 & 164.05 \\
\hline Dec. & 117.18 & 100.00 & 217.18 \\
\hline Jan.2005 & 187.50 & 40.62 & 228.12 \\
\hline Feb. & 178.12 & 54.68 & 232.8 \\
\hline Mar. & 189.06 & 62.50 & 251.56 \\
\hline Apr. & 209.37 & 128.12 & 337.49 \\
\hline May & 132.81 & 40.62 & 173.43 \\
\hline Jun. & 62.50 & 32.84 & 95.34 \\
\hline Jul. & 15.62 & 29.62 & 45.24 \\
\hline Aug. & 28.12 & 45.31 & 73.43 \\
\hline Mean & $\mathbf{1 1 5 . 4 9}$ & $\mathbf{5 3 . 1 1}$ & $\mathbf{1 6 8 . 6 1}$ \\
\hline S.D. & $\mathbf{6 6 . 1 1}$ & $\mathbf{3 0 . 7 4}$ & $\mathbf{8 7 . 4 4}$ \\
\hline
\end{tabular}


Vollenweider [13] classified the fresh water bodies as oligotrophic (GPP, $65-300 \mathrm{mgC} / \mathrm{m}^{3} /$ day) mesotrophic (GPP, $250-1000 \mathrm{mgC} / \mathrm{m}^{3} /$ day ) and eutrophic (GPP, 1000- $8000 \mathrm{mgC} / \mathrm{m}^{3} / \mathrm{day}$ ). The gross

primary production value of Mahakali river shows that the river is oligotrophic but developing a tendency as going towards mesotrophic.

\section{Acknowledgements}

Thanks are due to the campus chief of S.N. Science Campus, Mahendranagar for providing the necessary facilities to present work. The author is thankful also to Dr. (Mrs.) Manju Lata Bisht, Department of Zoology, D.S.B. Campus, Kumaun University, Nainital for her valuable guidance.

\section{References}

[1] K. L.Bisht, Advances in Limnology. Narendra Publishing House, Delhi (1993).

[2] D. R.Khanna, S. P. Badola and A. K.Dobriyal, Advances in Limnology. Narendra Publishing House, Delhi (1993).

[3] S. Dash, A. K. Patra and S Adhikary, J. Ecophysiol 11(2011) 219.

[4] P. V. Jabde and P. B. Rokade, An International Peer-Reviewed Journal, 3 (2014) 1.

[5] J. Sharma, Imperial Journal of Interdisciplinary Research 2 (2016) 460.

[6] T. Garder, and H. H. Gran, Et. Proc. - verb., Cons. Int. Explor. 42 (1927) 1.

[7] D. F. Westlake, Biol. Rev. 38 (1963) 385. http://dx.doi.org/10.1111/j.1469-185X.1963.tb00788.x

[8] G. E. Fogg, British phycological Bulletin. 2 (1963) 195.

[9] S. M. Das and V. K. Srivastava, Proc. Nat. Acad. Sci. India. 29 (1959) 174.

[10] B. D. Joshi, R. C. S. Bisht and Namita Joshi, Him, J. Env. Zool. 10 (1996) 31.

[11] Veena Baduni, Advances in Limnology. Narendra Publishing House, Delhi (1993).

[12] S. S.Pathani, Report Ministry of Environment and Forest Poryavaran Bhawan C.G.O. Complex, Lodi Road Delhi (1995).

[13] R. A.Vollenweider, I.B.P. Handbook 12, Blackwells, Oxford 12 (1974). 